University of South Florida

DIGITAL COMMONS

Digital Commons @ University of

@ UNIVERSITY OF SOUTH FLORIDA

South Florida

QMaSC: A Handbook for Directors of

Quantitative and Mathematics Support Centers

USF Libraries

$1-1-2016$

\title{
05. Strategic Planning and Budgeting
}

Gail Hilyard

Holyoke Community College

Follow this and additional works at: https://digitalcommons.usf.edu/qmasc_handbook

\section{Recommended Citation}

Gail Hilyard (2016), "Strategic Planning and Budgeting", http://dx.doi.org/10.5038/ 9780977674435.ch5 in G. Coulombe, M. O'Neill, M. Schuckers (Eds.) A Handbook for Directors of Quantitative and Mathematical Support Centers, Neck Quill Press, http://scholarcommons.usf.edu/qmasc_handbook.

This Center Leadership and Management is brought to you for free and open access by the USF Libraries at Digital Commons @ University of South Florida. It has been accepted for inclusion in QMaSC: A Handbook for Directors of Quantitative and Mathematics Support Centers by an authorized administrator of Digital Commons @ University of South Florida. For more information, please contact digitalcommons@usf.edu. 


\title{
Strategic Planning and Budgeting
}

\author{
(c) Gail Hilyard, \\ Holyoke Community College
}

吅

\section{Introduction}

Why do we strategically plan for quantitative and math support centers? Strategic planning is like a road map. It helps determine what direction we want to take our services by setting goals and objectives, and the goals help to standardize services and assess programs. The budget should align with the institution's strategic plan. It is crucial to identify diverse funding sources to be able to offer important future services. In determining goals, it is important to involve stakeholders such as senior administration, faculty, staff and students to ensure widespread support for the program. Once the strategic planning process has clarified the goals of the center, the director or coordinator must decide whether to implement a particular program to achieve them.

\section{Goals and Objectives}

All QMaSCs should have goals and objectives. Goals help to create the vision, and objectives help to break the plan down into manageable parts. Goals and objectives must be connected to the mission of the institution and its values, visions, and goals. For example, one institution's mission may be to provide comprehensive and high quality educational programs that will meet the intellectual and practical needs of a diverse student population [1]. The QMaSC must then attempt to align its goals with the institution's goals as stated in its mission. In addition, the

Suggested Citation: Gail Hilyard (2016), "Strategic Planning and Budgeting", http://dx.doi.org/10.5038/ 9780977674435.ch5 in G. Coulombe, M. O'Neill, M. Schuckers (Eds.) A Handbook for Directors of Quantitative and Mathematical Support Centers, Neck Quill Press, http://scholarcommons.usf.edu/qmasc_handbook.

This material is based upon work supported, in part, by the National Science Foundation under Grant DUE1255945. Any opinions, findings, and conclusions or recommendations expressed in this material are those of the author(s) and do not necessarily reflect the views of the National Science Foundation 
institutional mission may be to encourage and support a variety of instructional strategies [1]. Thus, the center at this institution might offer an assortment of contemporary instructional and supplemental support programs for students, including programs like the math learning coach, math mini prep, or e-tutoring. Likewise, the center services would try to support the lessons instructors are teaching in their classrooms. For another example, if the goal of the institution is to serve an economically, educationally, and linguistically diverse population and the student body reflects this goal, it is important for the director or coordinator to hire a diverse professional and peer tutoring staff that reflects the college's student profile. By adapting this hiring approach, this center may gain support for new and existing programs as well as being authorized to hire more tutors.

\section{Effect of Data on Budget and Strategic Planning}

Why collect center data? Because data give accountability and evidence of the need for financial support, data collection is vital for the survival of current and future support services in the center; therefore, the director/coordinator must collect student data. If the college has a longrange planning committee (LRPC), the center must tie its goals to the committee's goals: This helps show which center programs and activities are helping to achieve those goals set by the committee. It then becomes practical for the college to support the QMaSC budget for current and future services because center goals are aligned with LRPC and college goals. Some colleges collect student data manually — for instance, through a "Tutor Log" - while some may use a student tracking system software package - e.g. AccuTrack — and some may collect manual and electronic data at the same time to build in a backup system.

What types of data might be collected? The answer might depend on the characteristics of the students coming to the college: What are their learning gaps? What are their ethnic, socioeconomic, and linguistic backgrounds? And what type of support services are needed to help them succeed? The center should also collect data such as student identification numbers, appointment dates and durations, attendance, and grades (if the institution permits). The math center could even design its own survey to collect whatever data are needed. Collecting the above data will be useful in examining student retention, which tends to be an institutional goal at most colleges. If the data can show increased student achievement, which influences institutional retention, then it will be in the best interest of the institution to financially support programs and activities and future services in the center.

\section{Identifying Diverse Funding Sources}

It is important to target one's own college as a funding source by consulting with the development office, alumni office or grant writing division. There are also private funding sources like the 
Bill and Melinda Gates Foundation that support initiatives in education.

Several key funding sources can be used to help create a new center or support an existing one. Title III and Student Support Services (TRIO) grants are from the U.S. Department of Education. These federal grants are used to improve higher education in areas such as academic development and student support services. Another great source is STEM (Science, Technology, Engineering and Mathematics) funded by the National Science Foundation (NSF).

In Massachusetts, another funding source is the Vision Project Grant from the Department of Higher Education (DHE). This grant examines the role of public higher education in Massachusetts in comparison to other states, including factors such as graduation rates, student learning, and workforce development. The grant seeks to strengthen these areas, and other states may offer similar programs.

First Year Experience (FYE) Programs are funded by Strengthening Institutions Grants from the U. S. Department of Education. This program provides support for unique student subpopulations: underrepresented ethnic groups, specific genders, students with learning disability, etc.

\section{Involving Key Stakeholders in Program Development}

The involvement of stakeholders in program development is key to the success of present and future programs, projects, activities and initiatives.

How are stakeholders identified? Certain faculty or professional staff may ask the director/coordinator to do workshops with their students in the classroom or meeting room, or may bring their students to tour the QMaSC. They may also communicate their own ideas and concerns about center services. One way these genuinely interested stakeholders could serve is through an Advisory Committee; in this way, they will be able to enhance the services, vision and mission of the center. These individuals can help develop interdisciplinary strategies with other departments and clarify needs for the center. It can be especially helpful to have senior administration or other influential people serve on the Advisory Committee. The committee should be very diverse and have members from every aspect of the campus if possible.

In addition, it is very important to meet with the Vice President of Academic Affairs and other senior administration individually. The senior administration is faced with the difficult decision of what services, projects, programs, initiatives or activities to financially support. Therefore, it is imperative that the QMaSC director/coordinator show them how the center's goals are consistently meeting the goals of the administration. For example, student retention and course completion rates tend to be great concerns - keeping students in college is a huge issue for senior administration. The proposed goals of the center can become stakeholders' goals as they gain experience with the center's services and see that their goals are in alignment with the center's goals. These stakeholders, such 
as interested math department instructors, will then share the goals with other math instructors and the overall institution.

Specific programs could be developed through the strategic planning/budgeting process. Although not every institution will need any specific program, the following discussion will describe how a center director/coordinator could ask key questions to help decide whether to establish a particular type of program.

\section{One Example of How to Tie a Program to Budgets and Strategic Planning}

Some QMaSCs have developed a program called the Math Learning Coach to assist students and give them specialized one-on-one instruction. The program assists in breaking down the content and helping the student develop critical thinking skills and problem solving. The Math Learning Coach is often a professional mathematics specialist who identifies an individual student's learning styles and preferences, and develops an individual plan for each student to enhance her learning and success. See a more complete description of the program in the appendix.

What data should be examined by the director or coordinator to determine if this new initiative would be suitable for the institution? One important element to examine would be the characteristics of the student body at one's institution. For instance, a college might have a growing number of students who are coming to college with learning disabilities:

Nearly nine out of 10 of the nation's two- and four-year colleges enroll students with disabilities, and of the $86 \%$ of those that enroll students with learning disabilities, only $24 \%$ say they can help disabled students 'to a major extent' says an Education Department report published in June. Of about $67 \%$ of such students who pursued college or vocational school after high school, only $24 \%$ disclosed their impairment to college officials, a necessary first step toward getting accommodations, says a federally funded study that has tracked students from their teen years into young adulthood [2].

Likewise, a large segment of the student population may represent the first generation in their families to attend college. Many of these students have a difficult time succeeding in college. There could also be students who come with poor mathematical skills and a poor concept of their math ability that affects their learning [3].

How would the director/coordinator find out if the Math Learning Coach would be a good use of the center's budget? One might pilot the program for a year to see how beneficial it would be to students and whether an effective program could be aligned with LRPC goals.

If the pilot program indicates that the Math Learning Coaches are needed, then the data collection on the various student populations using this service would help show the need for this 
position: the data could show the benefit it has had for achievement, retention and completion rates, which are typically the goals of most institutions. The director or coordinator would need to track and collect the students' grades, attendance, subjects, and student comments on the coaches. The director or coordinator in that case would need to advocate for this position by meeting with all stakeholders, such as senior administration and the vice president from academic affairs, in order to secure financial support for this position.

\section{Summary}

First, one establishes goals and objectives connected to the mission of the institution. Then one needs to align one's budget with the goals and to use data collected to establish accountability for the center's programs. Seeking diverse funding sources from the college, governmental and private foundations may be helpful, and one cannot overestimate the importance of collaboration with key stakeholders. Every college has its own situations and priorities, so actual goals and objectives will vary.

\section{Bibliography}

[1] Holyoke Community College, "Mission statement." http://www.hcc.edu/about-hcc/ welcome/mission. Accessed June 14, 2013.

[2] M. B. Marklein, "Learning-disabled students get firmer grip on college." http://usatoday30. usatoday.com/news/education/story/2011-10-17/college-and-learningdisabilities/ 50807620/1. Accessed June 14, 2013.

[3] A. F. Gourgey, "Tutoring developmental mathematics: Overcoming anxiety and fostering independent learning," Journal of Developmental Education, vol. 15, no. 3, pp. 10-14, 1992.

\section{$9 \quad$ Further Reading}

J. Cullinane and P.U. Treisman, "What Policies and Practices Work for Students?," Prepared for the NCPR Developmental Education Conference Teachers College, Columbia University, Sept. 2010. Retrieved from http://www.postsecondaryresearch.org/conference/PDF/NCPR_ Panel4_CullinaneTreismanPaper_Statway.pdf

Massachusetts Community College Executive Office (MassCC). "100\% Math Initiative: Building a foundation for student success in developmental mathematics," 2006. Retrieved from http: //wWw.masscc.org/sites/massc.drupalgardens.com/files/mathinitiativefinal.pdf 


\section{Appendix}

The Math Learning Coach assists the student with:

- critical thinking skills

- reading comprehension

- time management

- study skills

- problem-solving

- note-taking

- test anxiety

Students set-up a schedule to meet with Math Learning Coaches on a weekly basis — sometimes 1, 2 or 3 times a week - depending on the need.

As part of the assessment and planning, the Math Learning Coach:

- Fills out a personal interview form with the student (15 to 20 minute)

- Administers an untimed diagnostic test to determine strengths and weakness, if needed

- Explores students' learning styles - LASSI (Learning and Study Strategies Inventory) and VARK Questionnaire (Visual Auditory Reading Kinesthetic)

- Recommends an academic plan in order to address both strengths and weaknesses

- Offers other resources to address weaknesses (videos, book, software, etc.) 